\title{
A genetic study of new udder health indicator traits with data from automatic milking systems
}

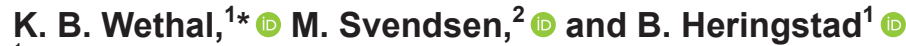 \\ ${ }^{1}$ Department of Animal and Aquacultural Sciences, Faculty of Biosciences, Norwegian University of Life Sciences, PO Box 5003,1432 Ås, \\ Norway \\ ${ }^{2}$ Geno Breeding and Al Association, 2326 Hamar, Norway
}

\begin{abstract}
The current study aimed to investigate new udder health traits based on data from automatic milking systems (AMS) for use in routine genetic evaluations. Data were from 77 commercial herds; out of these, 24 had equipment for measuring online cell count (OCC), whereas all had data on electrical conductivity (EC). A total of 4,714 Norwegian Red dairy cows and 2,363,928 milkings were included in the genetic analyses. Electrical conductivity was available on quarter level for each milking, whereas OCC was measured per milking. The AMS traits analyzed were log-transformed online cell count (lnOCC), maximum conductivity (ECmax), mean conductivity (ECmean), elevated mastitis risk (EMR), and log-transformed EMR (lnEMR). In addition, lactation mean somatic cell score (LSCS) was collected from the Norwegian dairy herd recording system. Elevated mastitis risk expresses the probability of a cow having mastitis and was calculated from smoothed $\operatorname{lnOCC}$ values according to individual trend and level of the OCC curve. The udder health traits from AMS were analyzed as repeated milkings from 30 to 320 DIM, and LSCS as repeated parities. In addition, both ECmax and $\operatorname{lnOCC}$ were analyzed as multiple traits by splitting the lactation into 5 periods. (Co)variance components were estimated from bivariate mixed linear animal models, and investigated traits showed genetic variation. Estimated heritabilities of ECmean, ECmax, and $\operatorname{lnEMR}$ were $0.35,0.23$, and 0.12 , respectively, whereas EMR and $\operatorname{lnOCC}$ both showed heritabilities of 0.09. Heritability varied between periods of lactation, from 0.04 to 0.13 for $\operatorname{lnOCC}$ and from 0.12 to 0.27 for ECmax, although standard errors of certain periods were large. Genetic correlations among the AMS traits ranged from 0 to 0.99 . The genetic correlations between EC-based traits and OCC-based traits in AMS were 0 . Genetic correlations with LSCS were favorable,
\end{abstract}

Received February 10, 2020.

Accepted March 27, 2020.

*Corresponding author: karoline.bakke@nmbu.no ranging from 0.37 to $0.80( \pm 0.11-0.22)$. The strongest correlation $(0.80 \pm 0.13)$ was found between LSCS and lnEMR. Results question the value of ECmax and ECmean as indicators of udder health in genetic evaluations and suggest OCC to be more valuable in this manner. This study demonstrates a potential of using AMS data as additional information on udder health for genetic evaluations, although further investigation is recommended before these traits can be implemented. Key words: mastitis indicator, online cell count, electrical conductivity, elevated mastitis risk, automatic milking system

\section{INTRODUCTION}

Automatic milking systems (AMS) provide frequent and objective measures with potential as indicators of udder health, which is of great importance for both economic and animal welfare reasons. The opportunity for longitudinal recording of udder health arises with sensors in AMS; this is especially relevant because mastitis is a complex trait. The disease varies from acute cases with clinical signs, such as warm and swollen udder and loss of milk production (Lohuis et al., 1990), to mild cases with few or subclinical mastitis without any visible signs (Oliveira et al., 2013). Veterinary-treated clinical mastitis (CM) and SCC in milk are the 2 main traits used in genetic evaluation of udder health (Heringstad et al., 2000). Udder health has been part of the breeding program for Norwegian Red (NR) since 1978. The prevalence of CM reported to the Norwegian Dairy Herd Recording System (NDHRS) declined from 0.22 cases per cow-year in 2002 to approximately 0.14 in 2018, and the trend is still decreasing (Tine, 2018). Although the prevalence of severe and acute CM has decreased, there are still challenges related to intramammary infections in dairy cattle, suggesting a need for alternative definitions of udder health for routine genetic evaluation. Treating CM as a binary trait analyzed by linear models leads to heritability estimates being generally low, varying from 0.01 to 0.035 (Luttinen and Juga, 1997; Heringstad et al., 1999; Rupp and Boichard, 
1999; Ødegård et al., 2004a). The indicator trait SCC is moderately correlated with $\mathrm{CM}$, with an average genetic correlation of 0.6 reported in the Nordic countries (Heringstad et al., 2000). Measurements of SCC are mainly based on monthly test-day records; thus, there may be time for an animal to get infected and recover from a mastitis case between test days, leading to undiscovered udder infections if information is based on test-day SCC. In AMS, repeated and objective records per milking are available and can be used for genetic evaluation purposes (Carlström et al., 2013; Wethal and Heringstad, 2019). In-line recording of online cell count (OCC; DeLaval, Tumba, Sweden) and electrical conductivity (EC) offers alternative phenotypes for continuous monitoring of udder health in AMS. Electrical conductivity is standard equipment and available from every AMS herd. Online cell counter is additional equipment and not yet available from every AMS herd. Heritability estimates of EC vary from 0.12 to 0.36 , and moderate genetic correlations with mastitis have been found, as reviewed by Norberg (2005).

Udder infections might be difficult to discover if clear clinical signs are lacking. Further, AMS herds may have a reduced time budget per cow, making it more challenging to discover intramammary infections. Therefore, sensor systems have been developed to detect mastitis and alert the farmer if the mastitis indicator reaches a certain level. The indicator may be based on changes in, for example, EC, milk yield, and milking speed. Based on OCC data, Sørensen et al. (2016) suggested elevated mastitis risk (EMR) on a 0-to-1 scale as an alternative measure of intramammary infection in AMS. An EMR closer to 1 indicates a larger probability for a cow to have mastitis, and the sensitivity for detecting true cases of CM has been reported to vary from 38 to $89 \%$ depending on specificity levels (Sørensen et al., 2016; Dalen et al., 2019). The ability of the EMR algorithm to detect subclinical mastitis caused by 2 groups of pathogens was reported with sensitivities from 12 to $69 \%$ for specificities of 80 to $90 \%$ (Dalen et al., 2019). Heritability of log-transformed EMR (InEMR) ranging from 0.06 to 0.15 was estimated by Sørensen and Løvendahl (2014). They reported that lnEMR had higher heritability than traditionally recorded CM. Comparing data on OCC, EC, and EMR from AMS with test-day SCC and records of CM from the NDHRS offers an opportunity to evaluate new phenotypes as additional information in the routine genetic evaluation of udder health.

The aim of this study was to estimate heritability of udder health indicator traits defined from OCC and EC data from AMS. We also aimed to estimate genetic correlations among udder health indicators from AMS and their genetic correlations with the lactation mean
SCS (LSCS) currently used in genetic evaluation of udder health.

\section{MATERIALS AND METHODS}

\section{Data Material}

Information included in the current study came from 77 Norwegian herds equipped with AMS from DeLaval (Tumba, Sweden). Data were gathered from 2016 to 2017 using remote desktop connections to the same herds as used in Wethal and Heringstad (2019). Due to memory limits, records per milking were available only $1 \mathrm{yr}$ back in time as data were deleted daily from the AMS. Before editing, the raw data contained approximately 4,900,000 observations, including both milkings and cows visiting the unit without milking permissions. Information about single milkings with known time and date were retained, together with information about EC, milk yield, and OCC. Records of EC were available per udder quarter at each milking in AMS. For OCC, records were available in only 24 herds because the equipment is optional. In these herds, OCC were at most available at milking level per cow. For all animals, additional information was extracted from the NDHRS, including birth date, calving dates, LSCS of the 3 first parities, and pedigree information. Records from first to ninth parity, within 30 to 320 DIM, and cows with a minimum of $9 \mathrm{~d}$ of milkings in AMS within a parity were included in the genetic analyses. Further, milk yield had to be $>0 \mathrm{~kg}$, whereas $\mathrm{EC} \leq 0.5 \mathrm{mS}$ and $\mathrm{OCC}$ $<500$ cells $/ \mathrm{mL}$ of milk were set to missing. Only purebred NR cows with a known NR AI sire were included in the genetic analyses. After editing, data contained information on EC from a total of 2,363,928 milkings for 4,714 cows, of which 1,490 cows had records on both EC and OCC from the AMS (Table 1). Pedigree was traced back 8 generations if possible, resulting in a total of 39,523 animals in the pedigree file.

\section{Traits}

During each milking, the EC of each udder quarter is measured in millisiemens. Change in EC is used as an indicator of udder health, where an increase may indicate an ongoing udder infection (Norberg et al., 2004a). Two traits were analyzed: maximum EC (ECmax), which was the highest value among the udder quarters at each milking, and mean EC (ECmean), which was the average value of all milked udder quarters at a given milking. Data on OCC were potentially available at each milking, but because the OCC unit can be switched off manually and farmers decide how often it should be used, the numbers of milkings and cows with 
Table 1. Number of observations (number of cows in parentheses) per trait combination of udder health traits ${ }^{1}$ from automatic milking systems (AMS) and lactation average SCS (LSCS) from the Norwegian dairy herd recording system (NDHRS)

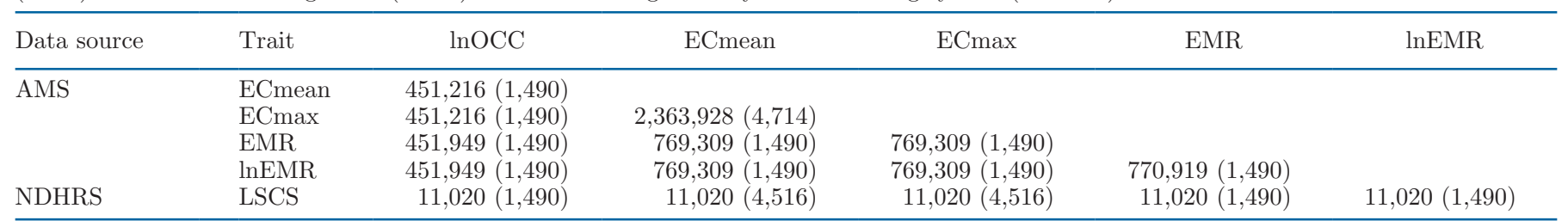

${ }^{1} \operatorname{lnOCC}=\log$-transformed online cell count; ECmean = mean electrical conductivity; ECmax = maximum electrical conductivity; EMR $=$ elevated mastitis risk; lnEMR $=$ log-transformed EMR.

OCC records were lower. Before further analyses, the OCC values were log-transformed (lnOCC) to obtain a more normally distributed trait. Further, lnOCC was used to estimate EMR, which expresses the probability of a cow having mastitis at a specific time in the lactation. Calculation of EMR followed Sørensen et al. (2016), adjusting lnOCC for machine-induced drift, before a double exponential Holt-Winter smoothing was applied to correct the trait for cow-level effects. Elevated mastitis risk is expressed on a continuous scale from 0 to 1 , with 0 indicating a healthy udder and 1 indicating infection. Both EMR and lnEMR were included for genetic analyses. Traits provided by AMS had 1 observation per milking. For cows with OCC records that had some milkings lacking OCC, predicted OCC values were derived from previous OCC measurements weighted together with values from a standard lactation curve using the Wilmink function (Wilmink, 1987). Predicted values were only used in the EMR calculations for the algorithm to continue at every time point, also for milkings without OCC values. Further, LSCS per parity up to third parity based on test-day records from NDHRS was available. Among the 4,714 cows with AMS records, 4,516 had data on LSCS, whereas 1,490 cows had records on $\operatorname{lnOCC}$ and lnEMR (Table 1). All traits based on AMS were analyzed as repeated records from 30 to 320 DIM; in addition, ECmax and $\operatorname{lnOCC}$ were defined as multiple traits within lactation by dividing the lactation into 5 periods.

\section{Descriptive Statistics}

The number of observations for the udder health indicator traits from AMS was 451,949 and 2,363,928 for OCC and EC, respectively. Descriptive statistics of lnOCC, ECmax, ECmean, EMR, and lnEMR measured in AMS are given in Table 2. An example of individual OCC and EC curves from continuous measurements in AMS is depicted in Figure 1.

\section{Traits with Repeated Milkings from 30 to 320 DIM}

Udder health indicators (LnOCC, ECmax, ECmean, EMR, and $\operatorname{lnEMR}$ ) were analyzed by repeatability models. Repeated milkings from 30 to 320 DIM were used. The traits were assumed to be consistent across parities, including all parities for (co)variance components estimation.

\section{Multiple Traits Within Lactation}

Maximum EC and $\operatorname{lnOCC}$ were also defined as different traits in periods of the lactation. Five periods (30-90, 90-150, 150-210, 210-270, and 270-320 DIM) were defined, and traits were assumed to be the same within a DIM period across parities. Genetic parameters were estimated to check for consistency across lactation stage.

Table 2. Descriptive statistics for repeated measures of log-transformed online cell count (lnOCC), maximum electrical conductivity (ECmax), average electrical conductivity (ECmean), elevated mastitis risk (EMR) and log-transformed EMR (lnEMR) in automatic milking systems and lactation average SCS (LSCS) from the first 3 parities (based on SCC test-day records)

\begin{tabular}{|c|c|c|c|c|c|c|}
\hline Trait & No. & Mean & $\mathrm{SD}$ & Minimum & Maximum & No. of animals \\
\hline $\operatorname{lnOCC}^{1}(\log$ cells $/ m L)$ & 451,949 & 4.48 & 1.15 & 0.69 & 9.12 & 1,490 \\
\hline $\mathrm{ECmax}^{1}(\mathrm{mS})$ & $2,363,928$ & 4.82 & 0.55 & 0.80 & 16.95 & 4,714 \\
\hline ECmean $^{1}(\mathrm{mS})$ & $2,363,928$ & 4.71 & 0.48 & 0.80 & 11.80 & 4,714 \\
\hline $\mathrm{EMR}^{1}$ & 770,919 & 0.11 & 0.20 & $0.39 \times 10^{-6}$ & 1 & 1,490 \\
\hline $\operatorname{lnEMR}{ }^{1}$ & 770,919 & -3.62 & 1.85 & -14.76 & 0 & 1,490 \\
\hline $\mathrm{LSCS}^{2}(\log$ cells $/ \mathrm{mL})$ & 11,020 & 4.32 & 0.89 & 2.02 & 8.67 & 4,516 \\
\hline
\end{tabular}

${ }^{1}$ Based on repeated milkings in automatic milking system from 30 to 320 DIM.

${ }^{2}$ Repeated over parities. 


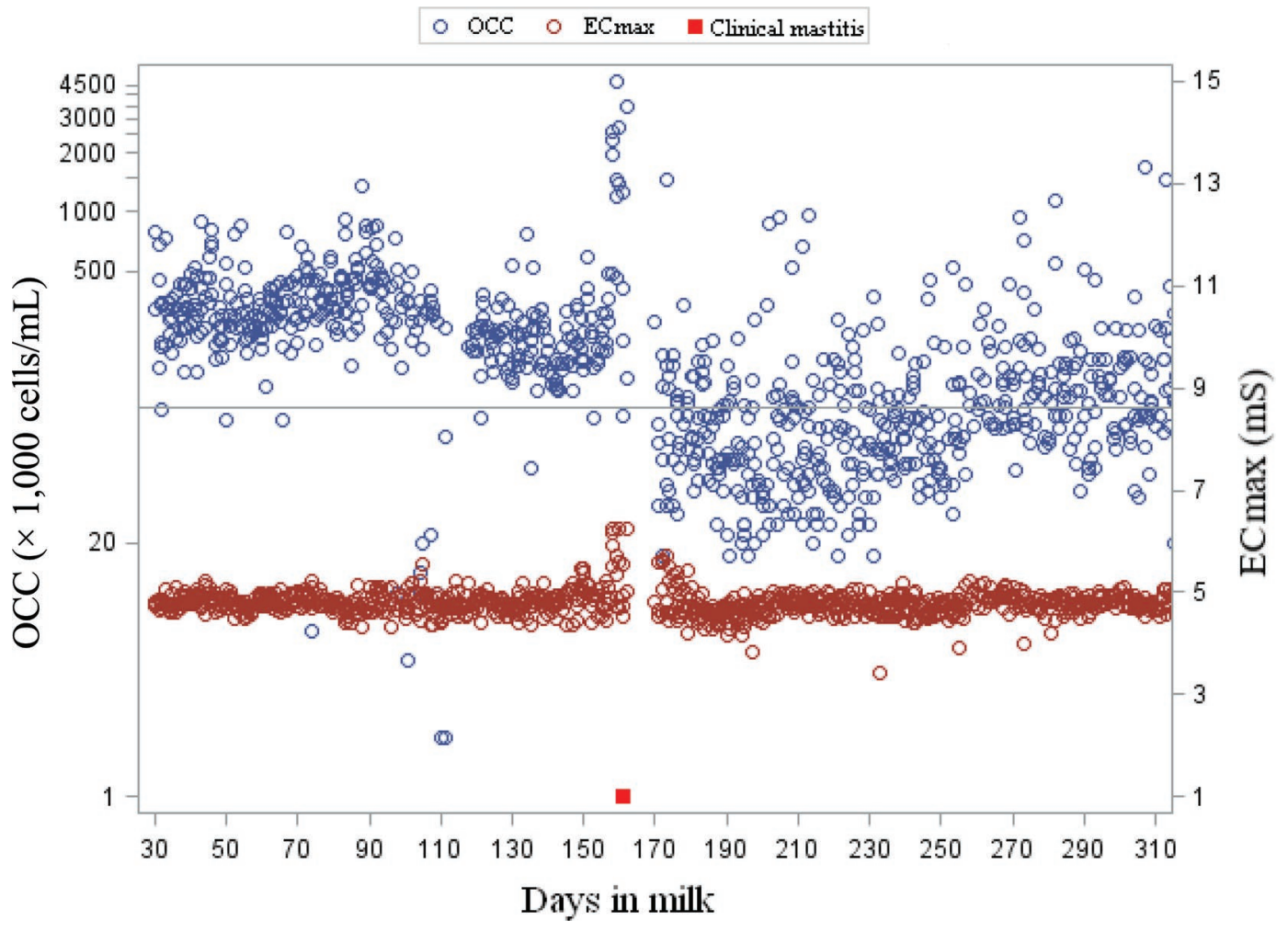

Figure 1. Plot of records for 1 cow with data from online cell count (OCC; in 1,000 cells/mL of milk) and maximum electrical conductivity (ECmax; in $\mathrm{mS}$ ). At around $160 \mathrm{DIM}$, an incident of mastitis occurred (red square indicates veterinary treatment of clinical mastitis), causing increased OCC and ECmax. The solid line indicates an SCC level of 100,000 cells/mL of milk.

\section{Calculation of EMR}

The main purpose of EMR is to characterize cows as healthy or sick on a continuous scale, giving the probability of udder infection at each milking. Elevated mastitis risk was calculated based on $\operatorname{lnOCC}$ following Sørensen et al. (2016). First, observations within a herd were adjusted based on the milking unit's deviation from an expected mean $\operatorname{lnOCC}$ value. Values in a time series might vary considerably from one time point to the next; therefore, single exponential smoothing as described by Hyndman et al. (2008) was applied. The single exponential smoothing of data points was done by sorting all the observations within herd by date and time of milking. Formula 1 in the supplemental material in Sørensen et al. (2016) was applied and updated with the smoothed level and trend at each time point. A weighted mean of past observations together with the current day's value was calculated, with larger weight put on newer records. This first step adjusted the raw OCC values within herd for drift in data. Second, a double exponential (Holt-Winter) smoothing was applied, mainly to adjust records according to the individual cow's OCC level and trend over time, resulting in a smoothed OCC curve for each cow. The smoothed OCC values adjusted for drift were used only if they deviated less than 2 log-units from the forecasted OCC value for the cow (see supplemental material in Sørensen et al., 2016). Missing OCC values were predicted using the previous known value, weighted together with expected values using the Wilmink function, in accordance with Sørensen et al. (2016). The double-smoothed OCC value was further used to calculate EMR. Factor analysis in SAS 9.4 (SAS Institute Inc., Cary, NC) was used to estimate factors for weighing level and trend. For each milking a latent variable was estimated and entered in the formula for calculating EMR (see the supplementary material in Sørensen et al., 2016). Elevated mastitis risk was calculated as follows:

$$
\mathrm{EMR}=\frac{1}{\left[1+e^{\left(-m-n \times \text { latent }^{\left(- \text {variable }_{k}\right)}\right]}\right.},
$$

where $m$ and $n$ were set to -3.5 and 2.3 , respectively, following Sørensen et al. (2016). The following formula was used to calculate a latent variable of the $k$ th milking: 
latent variable $_{k}=\left(\frac{S_{t}-\bar{S}}{\mathrm{SD} S}\right) \times \beta_{1 k}+\left(\frac{b_{t}-\bar{b}}{\mathrm{SD} b}\right) \times \beta_{2 k}$,

where $S_{t}$ and $b_{t}$ are the smoothed OCC level and OCC trend of the curve at a given time point $t$, respectively, and $\beta_{1 k}$ and $\beta_{2 k}$ are regression coefficients related to level and trend, respectively. Distribution of EMR was skewed toward larger frequency of animals with 0; thus, a log-transformation of EMR (lnEMR) was also carried out to ensure a more normal distribution.

\section{Statistical Methods}

For each analysis, the GLM procedure in SAS 9.4 (SAS Institute Inc.) was used to test for which fixed effects to include in the model. The DMUAI package of the DMU software (Madsen and Jensen, 2013) was used to estimate variance components. Bivariate mixed linear animal repeatability models were used for estimating heritabilities and genetic correlations between traits.

\section{Models for Udder Health in AMS}

For all traits measured in AMS the following linear animal repeatability model was used:

$$
\begin{aligned}
y_{\text {ghijklmn }}= & \mathrm{CYM}_{g}+\mathrm{CAP}_{h}+\mathrm{Mno}_{i}+\mathrm{DIM}_{j}+\mathrm{HY}_{k} \\
& +\mathrm{htd}_{l}+\mathrm{pe}_{m}+\mathrm{a}_{m}+\mathrm{e}_{\text {ghijklmn }},
\end{aligned}
$$

where $y_{\text {ghijklmn }}$ is the $n$th observation of $\operatorname{lnOCC}$, ECmean, ECmax, EMR, or lnEMR for cow $m$. The fixed effects were as follows: $\mathrm{CYM}_{g}$ is calving year and month $g$ from March 2015 to June 2017 (from 24 to 26 classes); $\mathrm{CAP}_{h}$ is calving age by parity number $h$ (37 classes); $\mathrm{Mno}_{i}$ is milking number $i$ within a day ( 5 classes); $\mathrm{DIM}_{j}$ is days in milk $j$ (291 or 50/60 classes); and $\mathrm{HY}_{k}$ is herd by year $k$ (from 47 to 151 classes). Random effects were as follows: $\operatorname{htd}_{l}$ is herd by test day $l(7,898-27,983$ levels); $\mathrm{pe}_{m}$ is permanent environmental effect of animal $m$ due to repeated milkings (from 1,490 to 4,714 levels); $\mathrm{a}_{m}$ is additive genetic animal effect; and $\mathrm{e}_{\text {ghijklmn }}$ is residual of each observation. Some fixed effect levels had few observations and were therefore merged. In parity 4 or later, age at calving was defined as one CAP class.

\section{Model for LSCS}

The following model was used for repeated LSCS observations:

$$
\begin{aligned}
y_{i j k l m n}=\mathrm{CYM}_{i} & +\mathrm{CAP}_{j}+\mathrm{DO}_{k}+\mathrm{HY}_{l}+\mathrm{pe}_{m} \\
& +\mathrm{a}_{m}+\mathrm{e}_{i j k l m n},
\end{aligned}
$$

where $y_{i j k l m n}$ is the LSCS observation for cow $m$ in parity $n$. Fixed effects were as follows: $\mathrm{CYM}_{i}$ is calving year and month $i$ (310 levels); $\mathrm{CAP}_{j}$ is calving age by parity number $j$ (58 levels); and $\mathrm{DO}_{k}$ is days open within parity, defined as days from calving to conception grouped in 10-d periods (42 levels, from 20 to 160 DIM). Random effects were as follows: $\mathrm{HY}_{l}$ is herd-year (757 levels); $\mathrm{pe}_{m}$ is permanent environment effect of cow due to repeated records over parities; and $\mathrm{a}_{m}$ and $\mathrm{e}_{i j k l m n}$ are as defined as earlier. For LSCS, CYM was from November 2005 to July 2019, and ages at calving ranged from 19 to 63 mo (parity 1 to 3 ).

\section{Assumptions for Bivariate Models}

Bivariate models were used for estimating genetic covariances between udder health traits defined as repeated milkings from 30 to 320 DIM. The following variance structure was assumed:

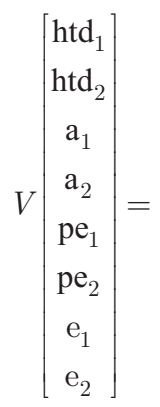

$$
\left[\begin{array}{cccccccc}
\mathbf{I} \sigma_{\mathrm{htd}_{1}}^{2} & \mathbf{I} \sigma_{\mathrm{htd}_{12}} & 0 & 0 & 0 & 0 & 0 & 0 \\
& \mathbf{I} \sigma_{\mathrm{htd}_{2}}^{2} & 0 & 0 & 0 & 0 & 0 & 0 \\
& & \mathbf{A} \sigma_{\mathrm{a}_{1}}^{2} & \mathbf{A} \sigma_{\mathrm{a}_{12}} & 0 & 0 & 0 & 0 \\
& & & \mathbf{A} \sigma_{\mathrm{a}_{2}}^{2} & 0 & 0 & 0 & 0 \\
& & & \mathbf{I} \sigma_{\mathrm{pe}_{1}}^{2} & \mathbf{I} \sigma_{\mathrm{pe}_{12}} & 0 & 0 \\
& & & & \mathbf{I} \sigma_{\mathrm{pe}_{2}}^{2} & 0 & 0 \\
& & & & & & \mathbf{I} \sigma_{\mathrm{e}_{1}}^{2} & \mathbf{I} \sigma_{\mathrm{e}_{12}} \\
& & & & & & & \mathbf{I} \sigma_{\mathrm{e}_{2}}^{2}
\end{array}\right],
$$

where $\sigma_{\mathrm{htd}_{i}}^{2}, \quad \sigma_{\mathrm{a}_{i}}^{2}, \quad \sigma_{\mathrm{pe}_{i}}^{2}$, and $\sigma_{\mathrm{e}_{i}}^{2}$ are the herd-test day, animal, permanent environmental, and residual variances, respectively, for the 2 traits $(i=1,2)$, and $\sigma_{\operatorname{htd}_{12}}$, $\sigma_{\mathrm{a}_{12}}, \sigma_{\mathrm{pe}_{12}}$, and $\sigma_{\mathrm{e}_{12}}$ are the corresponding covariances between traits. The random effect of herd by test day $\left(h_{t} d_{l}\right)$ was included due to the low frequency of OCC at specific test days and had the following distribution: htd $\sim N\left(0, \mathbf{I} \sigma_{\text {htd }}^{2}\right)$, where $\mathbf{I}$ is the identity matrix and $\sigma_{\text {htd }}^{2}$ is the herd-test day variance. Additive genetic ef- 
fect $\left(\mathrm{a}_{m}\right)$ of animal $m$ was assumed to be a $\sim N\left(0, \mathbf{A} \sigma_{\mathrm{a}}^{2}\right)$, where $\sigma_{\mathrm{a}}^{2}$ is the additive genetic variance and $\mathbf{A}$ is the relationship matrix that includes pedigree information on 39,523 animals. The random effect of permanent environment $\left(\mathrm{pe}_{m}\right)$ of animal $m$ was assumed to have the following distribution: pe $\sim N\left(0, \mathbf{I} \sigma_{\mathrm{pe}}^{2}\right)$, where $\sigma_{\mathrm{pe}}^{2}$ is the permanent environmental variance. The residual effect $\left(\mathrm{e}_{i j k l m n}\right)$ of observation $n$ was assumed to have the following distribution: $\mathrm{e} \sim N\left(0, \mathbf{I} \sigma_{\mathrm{e}}^{2}\right)$, where $\sigma_{\mathrm{e}}^{2}$ is the residual variance.

\section{Periods of DIM}

When estimating covariances between periods of the lactation for ECmax and lnOCC, the following assumptions were made for the residuals in the model:

$$
\left[\begin{array}{l}
\mathrm{e}_{1} \\
\mathrm{e}_{2}
\end{array}\right] \sim N\left[\left(\begin{array}{l}
0 \\
0
\end{array}\right), \quad \mathbf{I} \otimes\left(\begin{array}{cc}
\sigma_{\mathrm{e}_{1}}^{2} & 0 \\
0 & \sigma_{\mathrm{e}_{2}}^{2}
\end{array}\right)\right],
$$

where $\mathrm{e}_{1}$ and $\mathrm{e}_{2} \sim N\left(0, \sigma_{\mathrm{e}}^{2}\right), \mathrm{e}_{1}$ is residual variance of either $\operatorname{lnOCC}$ or ECmax for DIM period $i$, whereas $\mathrm{e}_{2}$ is residual variance for DIM period $j$ for the same trait; I is the identity matrix; $\otimes$ denotes the Kronecker product; and the residual variance for DIM periods $i$ and $j$ is denoted as $\sigma_{\mathrm{e}_{1}}^{2}$ and $\sigma_{\mathrm{e}_{2}}^{2}$, respectively. The DIM periods for the same cow occur at different time points or test days; consequently, the residual covariance between $\operatorname{traits}\left(\sigma_{\mathrm{e}_{12}}^{2}\right)$ was restricted to zero.

\section{Bivariate Models with LSCS}

For bivariate models with LSCS, assumptions of covariance structures for animal and permanent environmental effects were as defined in models for udder health traits in AMS. The effect of herd-year $\left(\mathrm{HY}_{l}\right)$ was included as random due to small subclasses with few animals and had the following distribution: $\mathrm{HY} \sim N\left(0, \mathbf{I} \sigma_{\mathrm{HY}}^{2}\right)$, where $\sigma_{\mathrm{HY}}^{2}$ is the herd-year variance and $\mathbf{I}$ is the identity matrix. Like in the models for periods of DIM, the residual covariances were restricted to zero.

\section{Heritability}

Heritability $\left(\mathrm{h}^{2}\right)$ of the traits was calculated using the following:

$$
\mathrm{h}^{2}=\frac{\sigma_{\mathrm{a}}^{2}}{\sigma_{\mathrm{a}}^{2}+\sigma_{\mathrm{pe}}^{2}+\sigma_{\mathrm{e}}^{2}},
$$

where $\sigma_{\mathrm{a}}^{2}$ is the additive genetic variance of animal, $\sigma_{\mathrm{pe}}^{2}$ is the permanent environment variance, and $\sigma_{\mathrm{e}}^{2}$ is the residual variance.

\section{Repeatability}

The repeatability $(\mathrm{R})$ was defined as the part of total phenotypic variation explained by the animal and was calculated as

$$
\mathrm{R}=\frac{\sigma_{\mathrm{a}}^{2}+\sigma_{\mathrm{pe}}^{2}}{\sigma_{\mathrm{p}}^{2}},
$$

where $\sigma_{\mathrm{p}}^{2}$ is the total phenotypic variance calculated from $\sigma_{\mathrm{a}}^{2}+\sigma_{\mathrm{pe}}^{2}+\sigma_{\mathrm{e}}^{2}$.

\section{Genetic Correlations}

Genetic correlation $\left(\mathrm{r}_{\mathrm{g}}\right)$ was calculated as

$$
\mathrm{r}_{\mathrm{g}}=\frac{\sigma_{\mathrm{a}_{1} \mathrm{a}_{2}}}{\sqrt{\sigma_{\mathrm{a}_{1}}^{2}, \sigma_{\mathrm{a}_{2}}^{2}}},
$$

where $\sigma_{\mathrm{a}_{1} \mathrm{a}_{2}}$ is the genetic covariance between traits and $\sigma_{\mathrm{a}_{1}}^{2}$ and $\sigma_{\mathrm{a}_{2}}^{2}$ are the additive genetic variance for traits 1 and 2 , respectively.

\section{RESULTS}

\section{Udder Health Traits from AMS}

Estimated variance components for udder health indicator traits in AMS based on repeated milkings from DIM 30 to 320 are given in Table 3. All heritabilities were significantly different from zero; LnOCC and EMR had the lowest heritabilities of 0.09, and ECmean had the largest heritability of 0.35 . When log-transforming EMR heritability increased to 0.12 . Repeatability varied from 0.47 to 0.90 ; lnOCC showed the lowest value and, as expected, LnEMR showed the highest value due to inclusion of smoothed OCC values corrected for effects not caused by animal factors. Log-transformed online cell count (LnOCC) showed large residual variance (almost $53 \%$ of the total phenotypic variance), whereas for $\operatorname{lnEMR}$ only $10 \%$ of the variation was unexplained by the model. 
Table 3. Estimated variance components, ${ }^{1}$ repeatability, ${ }^{2}$ and heritability ${ }^{3}$ (SE in parentheses) for log-transformed online cell count (lnOCC), electrical conductivity (EC) measured as maximum (ECmax) and mean (ECmean), elevated mastitis risk (EMR), and log-transformed EMR (lnEMR) from 30 to 320 DIM

\begin{tabular}{|c|c|c|c|c|c|c|}
\hline \multirow[b]{2}{*}{ Trait } & \multicolumn{4}{|c|}{ Variance component } & \multirow[b]{2}{*}{$\mathrm{R}$} & \multirow[b]{2}{*}{$\mathrm{h}^{2}$} \\
\hline & $\sigma_{\mathrm{a}}^{2}$ & $\sigma_{\mathrm{pe}}^{2}$ & $\sigma_{\text {htd }}^{2}$ & $\sigma_{\mathrm{e}}^{2}$ & & \\
\hline ECmax & $0.049(0.006)$ & $0.061(0.004)$ & $0.009(<0.001)$ & $0.105(<0.001)$ & $0.51(0.006)$ & $0.23(0.02)$ \\
\hline ECmean & $0.053(0.005)$ & $0.036(0.003)$ & $0.008(<0.001)$ & $0.062(<0.001)$ & $0.59(0.006)$ & $0.35(0.03)$ \\
\hline EMR & $0.004(0.002)$ & $0.037(0.002)$ & $0.0002(<0.0001)$ & $0.006(<0.0001)$ & $0.87(0.004)$ & $0.09(0.04)$ \\
\hline $\operatorname{lnEMR}$ & $0.43(0.17)$ & $2.77(0.18)$ & $0.033(<0.001)$ & $0.37(<0.001)$ & $0.90(0.004)$ & $0.12(0.04)$ \\
\hline
\end{tabular}

${ }^{1} \sigma_{\mathrm{a}}^{2}=$ additive genetic variance; $\sigma_{\mathrm{pe}}^{2}=$ permanent environment variance; $\sigma_{\mathrm{htd}}^{2}=$ herd test-day variance; $\sigma_{\mathrm{e}}^{2}=$ residual variance; $\sigma_{\mathrm{p}}^{2}=$ total phenotypic variance $\left(\sigma_{\mathrm{a}}^{2}+\sigma_{\mathrm{pe}}^{2}+\sigma_{\mathrm{e}}^{2}\right)$.

${ }^{2} \mathrm{R}=$ repeatability $\left(\sigma_{\mathrm{a}}^{2}+\sigma_{\mathrm{pe}}^{2}\right) / \sigma_{\mathrm{p}}^{2}$.

${ }^{3} \mathrm{~h}^{2}=$ heritability $\left(\sigma_{\mathrm{a}}^{2} / \sigma_{\mathrm{p}}^{2}\right)$.

Estimated genetic correlations between udder health indicator traits based on repeated milkings from DIM 30 to 320 varied from not significantly different from zero to close to 1 (Table 4 ). The strongest correlation was estimated between ECmean and ECmax (0.99). However, there were no genetic correlations between these 2 EC traits and lnOCC, EMR, or lnEMR. Genetic correlations with LSCS were significantly different from zero for all traits, ranging from 0.34 to 0.80 ; $\operatorname{lnOCC}$ and lnEMR showed the strongest correlations of 0.79 and 0.80 , respectively.

\section{DIM Periods of ECmax and InOCC}

Log-transformed online cell count and ECmax were also defined as different traits for 5 periods of the lactation. Heritabilities ranged from 0.04 to 0.13 for $\operatorname{lnOCC}$ and from 0.12 to 0.27 for ECmax. For the last 2 DIM periods the heritability for $\operatorname{lnOCC}$ increased, but for ECmax heritability was reduced from 0.27 in DIM 210 to 270 to 0.12 in DIM 270 to 320 . For lnOCC the largest heritability was at the last period of the lactation, but estimates had a large standard error due to the reduced number of animals.

Genetic correlations among the 5 periods were strong both for lnOCC (Table 5) and ECmax (Table 6). Genetic correlations between DIM periods varied from 0.60 to 0.99 for $\operatorname{lnOCC}$. For ECmax the genetic correlations among the periods were stronger, ranging from 0.81 to 1 . Adjacent periods had stronger correlations in general for both $\operatorname{lnOCC}$ and ECmax. Splitting the lactation into shorter periods was a first approach to investigating the variation in $\mathrm{EC}$ and $\mathrm{OCC}$ over time. Maximum EC had strong genetic correlation $(>0.92)$ among all periods except for 30 to 90 and 270 to 320 in DIM, suggesting that this trait is the same genetically throughout lactation and that defining the trait for different stages of lactation is not necessary. Genetic correlations of $\operatorname{lnOCC}$ were strong $(\geq 0.90)$ with low standard errors $(0.08-0.12)$ when adjacent periods were compared. Lowest correlation (0.60) was found between start of lactation and mid lactation (150-210 DIM), showing cell count in these periods to be most distinct.

Table 4. Genetic correlations (SE in parentheses) between udder health indicator traits from automatic milking systems $(\mathrm{AMS})^{1}$ and lactation average SCS (LSCS) from test-day records from the Norwegian Dairy Herd Recording System (Ås, Norway) ${ }^{2}$

\begin{tabular}{|c|c|c|c|c|c|}
\hline Trait & $\operatorname{lnOCC}$ & ECmax & ECmean & EMR & $\operatorname{lnEMR}$ \\
\hline ECmax & $-0.0004(0.17)$ & & & & \\
\hline ECmean & $0.04(0.16)$ & $0.99(0.002)$ & & & \\
\hline EMR & $0.50(0.22)$ & $-0.05(0.22)$ & $-0.03(0.21)$ & & \\
\hline $\operatorname{lnEMR}$ & $0.91(0.08)$ & $-0.05(0.22)$ & $-0.008(0.20)$ & $0.76(0.15)$ & \\
\hline LSCS & $0.79(0.11)$ & $0.34(0.11)$ & $0.37(0.10)$ & $0.58(0.22)$ & $0.80(0.13)$ \\
\hline
\end{tabular}

${ }^{1} \ln \mathrm{OCC}=\log$-transformed online cell count in milk; ECmax = maximum electrical conductivity; ECmean = mean electrical conductivity; EMR = elevated mastitis risk; $\operatorname{lnEMR}=\log$-transformed EMR.

${ }^{2}$ Traits were recorded in AMS with 1 record per milking and cow from 30 to 320 DIM and were recorded in LSCS as repeated records from first to third parity. 
Table 5. Heritability on the diagonal and genetic correlations below the diagonal (SE in parentheses) between log-transformed online cell count from automatic milking systems at different DIM periods

\begin{tabular}{lccccc}
\hline DIM period & $30-90$ & $90-150$ & $150-210$ & $210-270$ & $270-320$ \\
\hline $30-90$ & $0.09(0.04)$ & $0.92(0.09)$ & $0.07(0.03)$ & & \\
$90-150$ & $0.60(0.24)$ & $0.90(0.11)$ & $0.04(0.03)$ & & \\
$150-210$ & $0.75(0.21)$ & $0.78(0.22)$ & $0.99(0.12)$ & $0.09(0.04)$ & \\
$210-270$ & $0.83(0.21)$ & $0.79(0.23)$ & $0.92(0.23)$ & $0.99(0.08)$ & $0.13(0.06)$ \\
$270-320$ & &
\end{tabular}

\section{DISCUSSION}

\section{Genetic Variances and Repeatability}

This study successfully estimated heritabilities for all udder health indicator traits measured in-line during milking in AMS and found significant genetic correlations with LSCS. As previous studies mostly focused on the use of sensor data in AMS for herd-management purposes, results to compare with are scarce. Only Sørensen and Løvendahl (2014) have analyzed OCC and EMR genetically. They divided first parity into periods of $30 \mathrm{~d}$ and estimated heritabilities of $\operatorname{lnOCC}$ from 0.06 to 0.14 . This is in good agreement with the heritability estimates of 0.04 to 0.13 for $\operatorname{lnOCC}$ in 5 different DIM periods found in our study. Although few genetic studies of OCC in AMS have been conducted so far, the genetic nature of test-day SCC and LSCS has been widely investigated (e.g., Emanuelson et al., 1988; Ødegård et al., 2003, 2004b; Heringstad et al., 2008). In general, the heritability of SCC when defined as a mean value over the lactation ranged from 0.11 to 0.26 (Luttinen and Juga, 1997; Ødegård et al., 2004b; Kirsanova et al., 2019). These estimates were mostly larger than what we found for lnOCC. It is generally known that averaging records of a trait over a longer period increases heritability; thus, larger estimates would be expected if OCC were summarized over a longer period.

The heritability estimates of ECmax (0.23) and ECmean (0.35) were in line with results reported by Norberg et al. (2004c), who found heritability of 0.28 for EC measured as a daily mean in first-parity Holsteins. Further, they reported heritabilities ranging from 0.26 to 0.36 using random regression models with Legendre polynomials. Heritability of ECmean and EC$\max$ were also in agreement with the estimate of 0.23 for log-transformed EC measured as maximum values from each milking (Povinelli et al., 2005). Santos et al. (2018) found even larger heritability of 0.53 for EC measured at cow level and 0.37 to 0.46 for udder quarters in a study based on data from 3 herds for 1 period of $30 \mathrm{~d}$. When EC was measured as interquarter ratio between the individual teats with the highest and lowest EC values, heritabilities were relatively low, ranging from 0.05 to 0.12 in Norberg et al. (2004b). They found this definition of EC to work better for detecting CM. Preliminary results of the current study did not find any significant additive genetic variance of interquarter ratio (results not shown). This may be related to small differences in EC between udder quarters in our data. Another difference is that our data contained 1 record of ECmean and ECmax per udder quarter per milking, whereas in Norberg et al. (2004b) EC was measured every $2 \mathrm{~s}$.

The heritability estimates of EMR (0.09) and lnEMR (0.12) were in the same range as reported by Sørensen and Løvendahl (2014), who estimated heritabilities from 0.06 to 0.15 for $\operatorname{lnEMR}$ and from 0.02 to 0.09 for EMR in first-parity Holsteins at different periods of DIM. In their study, EMR did not show genetic variance significantly different from zero for some of the investigated periods of lactation; thus, they argue that lnEMR may be a better definition than EMR. The current study did not investigate EMR in shorter periods of DIM, but it would be relevant to check whether the trait differs genetically throughout the lactation. When calculating EMR, OCC measurements from $6 \mathrm{~d}$ after calving were included in the algorithm in order to ensure fast stabilization of the smoothed OCC values before genetic components were estimated. The genetic analyses included only records after 30 DIM to avoid the period of elevated SCC level right after calving.

Table 6. Heritability on the diagonal and genetic correlations below the diagonal (SE in parentheses) between maximum electrical conductivity measured by automatic milking systems at different DIM periods

\begin{tabular}{lccccc}
\hline DIM period & $30-90$ & $90-150$ & $150-210$ & $210-270$ & $270-320$ \\
\hline $30-90$ & $0.26(0.03)$ & & & & \\
$90-150$ & $0.98(0.01)$ & $0.27(0.03)$ & & & \\
$150-210$ & $0.93(0.03)$ & $0.98(0.01)$ & $0.27(0.04)$ & & \\
$210-270$ & $0.92(0.04)$ & $0.99(0.02)$ & $1.00(0.01)$ & $0.16(0.03)$ & \\
$270-320$ & $0.81(0.08)$ & $0.92(0.06)$ & $0.94(0.05)$ & $0.98(0.02)$ & $0.12(0.04)$ \\
\hline
\end{tabular}


Heritability estimates for $\operatorname{lnOCC}$ showed higher heritability toward the end of lactation. A similar pattern was reported for heritability of test-day SCC analyzed by random regression models (Norberg et al., 2004b). In the study by Sørensen and Løvendahl (2014), heritability of $\operatorname{lnOCC}$ increased steadily and peaked around 200 DIM. The pattern was opposite for the heritability of ECmax, where heritability decreased drastically after 200 DIM. Larger genetic variation in the first period of lactation was also found for CM (Lund et al., 1999; Heringstad et al., 2003b) and for both test-day SCS and EC defined as an interquarter ratio analyzed by random regression models (Norberg et al., 2004b). Larger genetic variation for EC in the first part of the lactation may be due to increased frequency of infection in this period. Larger genetic variation and frequency of $\mathrm{CM}$ in early lactation have been reported earlier (Heringstad et al., 2003a). Repeatability of lnOCC was low (0.47) compared with the high repeatability observed for EMR and lnEMR (0.90). This was in line with the study by Sørensen and Løvendahl (2014) and likely caused by the smoothing process used for EMR. Therefore, EMR observations showed less variation over time and to a larger degree were explained by effects of the animal itself (i.e., permanent nongenetic and genetic effects).

\section{Genetic Correlations}

Genetic correlations of zero between $\operatorname{lnOCC}$ and the 2 EC traits were not expected and are not comparable with other studies at this point. The genetic correlation of 0.86 between test-day SCC and EC defined as an interquarter ratio in the first month of lactation reported by Norberg et al. (2004b) suggests that a genetic relationship exists. However, when EC and in-line measurements of SCC from the same milkings were compared, a phenotypic correlation $<0.4$ was reported by Hovinen et al. (2006) for commercial AMS farms. These authors also reported that measurements of EC alone were very poor at detecting SCC level in milk. Others do report a low phenotypic correlation between SCS from herd test-day records and EC (Nielen et al., 1992; Hovinen et al., 2006; Vilas Boas et al., 2017). Considering the larger number of animals from different herds in the current study, we consider the results to be reliable even though they contradict earlier findings.

Strong and favorable genetic correlations of LSCS with $\operatorname{lnOCC}$ and lnEMR (0.79 and 0.80, respectively) in AMS confirm that in-line records of cell count in milk provide accurate measurements related to those already included in the NDHRS. However, a correlation less than unity indicates that OCC may also contribute some complementary genetic information. Clinical mas- titis is also included in the udder health index for NR. However, the genetic relationship with EMR could not be investigated in the current study due to the limited number of animals and very low frequency of $\mathrm{CM}$ in the material ( $\sim 4 \%)$. Sørensen and Løvendahl (2014) could not estimate the relationship between EMR and CM for the same reason. Many studies have estimated the relationship between traditionally measured SCC and $\mathrm{CM}$, yielding genetic correlations ranging from 0.37 to 0.97 (Lund et al., 1994; Pösö and Mäntysaari, 1996; Koeck et al., 2010). Results based on a large data set of first-parity NR cows show a genetic correlation between CM and LSCS of 0.53 (Ødegård et al., 2004b). The genetic correlation between CM and EMR should be estimated to evaluate how well it is capturing CM cases. Even though the numbers of herds and observations were large in our study, the time period for extracting detailed data from each farm was relatively short, mainly due to memory limitations in the AMS software.

In the current study, traits were assumed to be the same across parities because of a limited number of cows. This assumption should be checked with more cows in the data set for OCC traits. However, many studies have estimated strong genetic correlations, ranging from 0.70 to 1.0 , between $\mathrm{CM}$ across parities (Pösö and Mäntysaari, 1996; Nielsen et al., 1997; Carlén et al., 2004; Urioste et al., 2012). Also, SCC and LSCS are genetically correlated across lactations (Pösö and Mäntysaari, 1996; Samoré et al., 2008; Urioste et al., 2012). Genetic correlation between log SCC measured early and late in lactation has been reported in the range from 0.14 to 0.55 for first- to third-parity Holsteins, whereas adjacent periods in the same lactation were highly correlated and reported to be almost unity (Haile-Mariam et al., 2001). If the genetic correlation of test-day SCC or OCC in different lactation periods or parities is $<1$, alternative models such as the multitrait model or random regression model should be considered to take the time aspect into account and use the information from the different periods.

\section{Implications and Further Recommendations}

This is the first genetic study of large-scale udder health indicator traits from OCC recorded during milking in AMS. Studies investigating OCC have so far been based on data from 1 farm (research farm) to 8 farms (commercial farms; Sørensen and Løvendahl, 2014; Sørensen et al., 2016; Dalen et al., 2019), but these studies were not genetic studies. However, more data are still needed to estimate genetic correlations with $\mathrm{CM}$ and to investigate alternative trait definitions. 
Average OCC in the current study was slightly higher $(88,000$ cells $/ \mathrm{mL})$ than average test-day SCC in the NDHRS $(75,000$ cells $/ \mathrm{mL})$. Herds investing in OCC equipment may have elevated SCC level in milk and thereby be more motivated to monitor OCC. The frequency of cows reported with $\mathrm{CM}$ in these herds was slightly higher $(\sim 6 \%)$ compared with the average for the AMS herds without the OCC equipment $(\sim 3 \%)$. Another aspect may be that these herds were relatively large, which made it more challenging to monitor individual cows.

A high level of OCC in milk over time may indicate an ongoing subclinical infection with bacteria that might be transmitted; hence, this trait is relevant in selection for improved udder health. Further studies are needed to clarify the usefulness of EC as an indicator of udder health, including genetic correlations with CM, to understand how well udder health is measured.

When OCC measured in AMS was compared with test-day SCC from milk recordings, the correlation between them was strong (Sørensen et al., 2016; Nørstebø et al., 2019). The current study did confirm a strong genetic agreement between OCC and LSCS, which supports in-line-measured cell count as an indicator of udder health. Health indicators from AMS do provide more precise information due to repeated records from every milking. Continuous data present opportunities for new udder health traits, such as individual cows' susceptibility to udder infections and their ability to recover after being infected (Franzén et al., 2012; Welderufael et al., 2017). Elevated mastitis risk could cover other aspects of susceptibility to mastitis, such as number of days from calving to first EMR value above some fixed threshold. Other alternative traits could be days (or hours) from infection to recovery, or whether the animal recovers without treatment. Results from the current study show that data from AMS can contribute additional udder health traits for use in genetic evaluation.

\section{CONCLUSIONS}

Udder health indicator traits based on EC and OCC data recorded in commercial AMS herds were heritable and might contribute genetic information on longitudinal udder health. All traits were genetically correlated with LSCS, a trait included in the routine genetic evaluations of udder health today. The strongest genetic correlation with LSCS was estimated for $\operatorname{lnOCC}$ and $\operatorname{lnEMR}$, and the lowest with the EC traits. No genetic correlations were found between OCC-based traits and the 2 EC traits. Despite high heritability, their importance as indicator traits for improved udder health is unclear, whereas traits based on OCC from AMS are promising.

\section{ACKNOWLEDGMENTS}

The authors acknowledge the Norwegian Dairy Herd Recording System (Ås, Norway) for providing data and Geno Breeding and AI Association (Hamar, Norway) for contributing to this project. This research was part of "AMS-project; New approaches to management and breeding of dairy cows, in automatic milking systems." The industrial partners involved and the Norwegian University of Life Sciences (Ås, Norway) are also acknowledged. Last, we thank all the Norwegian dairy farmers contributing data, making this study possible. The authors have not stated any conflicts of interest.

\section{REFERENCES}

Carlén, E., E. Strandberg, and A. Roth. 2004. Genetic parameters for clinical mastitis, somatic cell score, and production in the first three lactations of Swedish Holstein cows. J. Dairy Sci. 87:30623070. https://doi.org/10.3168/jds.S0022-0302(04)73439-6.

Carlström, C., G. Pettersson, K. Johansson, E. Strandberg, H. Stålhammar, and J. Philipsson. 2013. Feasibility of using automatic milking system data from commercial herds for genetic analysis of milkability. J. Dairy Sci. 96:5324-5332. https://doi.org/10.3168/ jds.2012-6221.

Dalen, G., A. Rachah, H. Nørstebø, Y. H. Schukken, and O. Reksen. 2019. The detection of intramammary infections using online somatic cell counts. J. Dairy Sci. 102:5419-5429. https://doi.org/10 $.3168 /$ jds.2018-15295.

Emanuelson, U., B. Danell, and J. Philipsson. 1988. Genetic parameters for clinical mastitis, somatic cell counts, and milk production estimated by multiple-trait restricted maximum likelihood. J. Dairy Sci. 71:467-476. https://doi.org/10.3168/jds.S0022 -0302(88)79576-4.

Franzén, J., D. Thorburn, J. I. Urioste, and E. Strandberg. 2012. Genetic evaluation of mastitis liability and recovery through longitudinal analysis of transition probabilities. Genet. Sel. Evol. 44:10 https://doi.org/10.1186/1297-9686-44-10.

Haile-Mariam, M., M. E. Goddard, and P. J. Bowman. 2001. Estimates of genetic parameters for daily somatic cell count of Australian dairy cattle. J. Dairy Sci. 84:1255-1264. https://doi.org/10 .3168/jds.S0022-0302(01)74587-0.

Heringstad, B., Y. M. Chang, D. Gianola, and G. Klemetsdal. 2003a. Genetic analysis of longitudinal trajectory of clinical mastitis in first-lactation Norwegian cattle. J. Dairy Sci. 86:2676-2683. https: //doi.org/10.3168/jds.S0022-0302(03)73863-6.

Heringstad, B., G. Klemetsdal, and J. Ruane. 1999. Clinical mastitis in Norwegian cattle: Frequency, variance components, and genetic correlation with protein yield. J. Dairy Sci. 82:1325-1330. https:/ /doi.org/10.3168/jds.S0022-0302(99)75356-7.

Heringstad, B., G. Klemetsdal, and J. Ruane. 2000. Selection for mastitis resistance in dairy cattle: A review with focus on the situation in the Nordic countries. Livest. Prod. Sci. 64:95-106. https://doi .org/10.1016/S0301-6226(99)00128-1.

Heringstad, B., R. Rekaya, D. Gianola, G. Klemetsdal, and K. A. Weigel. 2003b. Genetic change for clinical mastitis in Norwegian cattle: A threshold model analysis. J. Dairy Sci. 86:369-375. https: //doi.org/10.3168/jds.S0022-0302(03)73615-7.

Heringstad, B., E. Sehested, and T. Steine. 2008. Short communication: Correlated selection responses in somatic cell count from selection against clinical mastitis. J. Dairy Sci. 91:4437-4439. https: //doi.org/10.3168/jds.2008-1330.

Hovinen, M., A.-M. Aisla, and S. Pyörälä. 2006. Accuracy and reliability of mastitis detection with electrical conductivity and milk colour measurement in automatic milking. Acta Agric. Scand. A Anim. Sci. 56:121-127. https://doi.org/10.1080/09064700701216888. 
Hyndman, R. J., A. B. Koehler, J. K. Ord, and R. D. Snyder. 2008. Forecasting with Exponential Smooting. Springer-Verlag, Berlin, Germany.

Kirsanova, E., B. Heringstad, A. Lewandowska-Sabat, and I. Olsaker. 2019. Alternative subclinical mastitis traits for genetic evaluation in dairy cattle. J. Dairy Sci. 102:5323-5329. https://doi.org/10 .3168/jds.2018-16104.

Koeck, A., B. Heringstad, C. Egger-Danner, C. Fuerst, P. Winter, and B. Fuerst-Waltl. 2010. Genetic analysis of clinical mastitis and somatic cell count traits in Austrian Fleckvieh cows. J. Dairy Sci. 93:5987-5995. https://doi.org/10.3168/jds.2010-3451.

Lohuis, J. A. C. M., Y. H. Schukken, J. H. M. Verheijden, A. Brand, and A. S. J. P. A. M. Van Miert. 1990. Effect of severity of systemic signs during the acute phase of experimentally induced Escherichia coli mastitis on milk production losses. J. Dairy Sci. 73:333-341. https://doi.org/10.3168/jds.S0022-0302(90)78678-X.

Lund, M. S., J. Jensen, and P. H. Petersen. 1999. Estimation of genetic and phenotypic parameters for clinical mastitis, somatic cell production deviance, and protein yield in dairy cattle using Gibbs sampling. J. Dairy Sci. 82:1045-1051. https://doi.org/10.3168/jds .S0022-0302(99)75325-7.

Lund, T., F. Miglior, J. C. M. Dekkers, and E. B. Burnside. 1994 Genetic relationships between clinical mastitis, somatic cell count, and udder conformation in Danish Holsteins. Livest. Prod. Sci. 39:243-251. https://doi.org/10.1016/0301-6226(94)90203-8.

Luttinen, A., and J. Juga. 1997. Genetic relationships between milk yield, somatic cell count, mastitis, milkability and leakage in Finnish dairy cattle population. Interbull Bull. 15:78-83.

Madsen, P., and J. Jensen. 2013. A user's guide to DMU. A package for analysing multivariate mixed models. Cent. Quant. Genet. Genomics Dept. Mol. Biol. Genet. Univ. Aarhus Res. Cent., Tjele Denmark.

Nielen, M., H. Deluyker, Y. H. Schukken, and A. Brand. 1992. Electrical conductivity of milk: Measurement, modifiers, and meta analysis of mastitis detection performance. J. Dairy Sci. 75:606-614. https://doi.org/10.3168/jds.S0022-0302(92)77798-4.

Nielsen, U. S., G. A. Pedersen, J. Pedersen, and J. Jensen. 1997. Genetic correlations among health traits in different lactations. Interbull Bull. 15:68-77.

Norberg, E. 2005. Electrical conductivity of milk as a phenotypic and genetic indicator of bovine mastitis: A review. Livest. Prod. Sci. 96:129-139. https://doi.org/10.1016/j.livprodsci.2004.12.014.

Norberg, E., H. Hogeveen, I. R. Korsgaard, N. C. Friggens, K. H. M. N. Sloth, and P. Løvendahl. 2004a. Electrical conductivity of milk: Ability to predict mastitis status. J. Dairy Sci. 87:1099-1107. https://doi.org/10.3168/jds.S0022-0302(04)73256-7.

Norberg, E., J. Ødegård, and P. Madsen. 2004b. Comparison of variance components for test-day electrical conductivity of milk and test-day somatic cell score for first lactation cows in an experimental herd. Acta Agric. Scand. A Anim. Sci. 54:181-186. https://doi .org/10.1080/09064700410010035.

Norberg, E., G. W. Rogers, R. C. Goodling, J. B. Cooper, and P. Madsen. 2004c. Genetic parameters for test-day electrical conductivity of milk for first-lactation cows from random regression models. J. Dairy Sci. 87:1917-1924. https://doi.org/10.3168/jds.S0022 -0302(04)73350-0.

Nørstebø, H., G. Dalen, A. Rachah, B. Heringstad, A. C. Whist, A. Nødtvedt, and O. Reksen. 2019. Factors associated with milkingto-milking variability in somatic cell counts from healthy cows in an automatic milking system. Prev. Vet. Med. 172:104786. https:/ /doi.org/10.1016/j.prevetmed.2019.104786.

Ødegård, J., B. Heringstad, and G. Klemetsdal. 2004a. Short communication: Bivariate genetic analysis of clinical mastitis and somatic cell count in Norwegian dairy cattle. J. Dairy Sci. 87:3515-3517. https://doi.org/10.3168/jds.S0022-0302(04)73487-6.

Ødegård, J., B. Heringstad, and G. Klemetsdal. 2004b. Short communication: Bivariate genetic analysis of clinical mastitis and somatic cell count in Norwegian dairy cattle. J. Dairy Sci. 87:3515-3517. https://doi.org/10.3168/jds.S0022-0302(04)73487-6.

Ødegård, J., G. Klemetsdal, and B. Heringstad. 2003. Variance components and genetic trend for somatic cell count in Norwegian cattle. Livest. Prod. Sci. 79:135-144. https://doi.org/10.1016/ S0301-6226(02)00148-3.

Oliveira, L., C. Hulland, and P. L. Ruegg. 2013. Characterization of clinical mastitis occurring in cows on 50 large dairy herds in Wisconsin. J. Dairy Sci. 96:7538-7549. https://doi.org/10.3168/jds .2012-6078.

Pösö, J., and E. A. Mäntysaari. 1996. Relationships between clinical mastitis, somatic cell score, and production for the first three lactations of Finnish Ayrshire. J. Dairy Sci. 79:1284-1291. https:// doi.org/10.3168/jds.S0022-0302(96)76483-4.

Povinelli, M., L. Gallo, P. Carnier, D. Marcomin, R. D. Zotto, and M. Cassandro. 2005. Genetic aspects of milk electrical conductivity in Italian Brown cattle. Ital. J. Anim. Sci. 4(Suppl. 3):169-171. https: //doi.org/10.4081/ijas.2005.3s.169.

Rupp, R., and D. Boichard. 1999. Genetic parameters for clinical mastitis, somatic cell score, production, udder type traits, and milking ease in first lactation Holsteins. J. Dairy Sci. 82:2198-2204. https: //doi.org/10.3168/jds.S0022-0302(99)75465-2.

Samoré, A. B., A. F. Groen, P. J. Boettcher, J. Jamrozik, F. Canavesi, and A. Bagnato. 2008. Genetic correlation patterns between somatic cell score and protein yield in the Italian Holstein-Friesian population. J. Dairy Sci. 91:4013-4021. https://doi.org/10.3168/ jds.2007-0718.

Santos, L. V., K. Brügemann, A. Ebinghaus, and S. König. 2018. Genetic parameters for longitudinal behavior and health indicator traits generated in automatic milking systems. Arch. Tierzucht 61:161-171. https://doi.org/10.5194/aab-61-161-2018.

Sørensen, L. P., M. Bjerring, and P. Løvendahl. 2016. Monitoring individual cow udder health in automated milking systems using online somatic cell counts. J. Dairy Sci. 99:608-620. https://doi .org/10.3168/jds.2014-8823.

Sørensen, L. P., and P. Løvendahl. 2014. Genetic analysis of elevated mastitis risk based on mastitis indicator data. Page 536 in Proceedings of the 10th World Congress on Genetics Applied to Livestock Production, Vancouver, BC, Canada.

Tine. 2018. Statistikksamling Fra Ku- Og Geitekontrollen 2018. Table H3 (in Norwegian, tables in English). Accessed Nov. 13 2019. https://medlem.tine.no/aktuelt/nyheter/hk-statistikker/ _attachment/476965?_ts=169bdf74e93.

Urioste, J. I., J. Franzén, J. J. Windig, and E. Strandberg. 2012 Genetic relationships among mastitis and alternative somatic cell count traits in the first 3 lactations of Swedish Holsteins. J. Dairy Sci. 95:3428-3434. https://doi.org/10.3168/jds.2011-4739.

Vilas Boas, D. F., A. E. Vercesi Filho, M. A. Pereira, L. C. Roma Junior, and L. El Faro. 2017. Association between electrical conductivity and milk production traits in dairy Gyr cows. J. Appl. Anim. Res. 45:227-233. https://doi.org/10.1080/09712119.2016 .1150849 .

Welderufael, B. G., L. L. G. Janss, D. J. de Koning, L. P. Sørensen, P. Løvendahl, and W. F. Fikse. 2017. Bivariate threshold models for genetic evaluation of susceptibility to and ability to recover from mastitis in Danish Holstein cows. J. Dairy Sci. 100:4706-4720. https://doi.org/10.3168/jds.2016-11894.

Wethal, K. B., and B. Heringstad. 2019. Genetic analyses of novel temperament and milkability traits in Norwegian Red cattle based on data from automatic milking systems. J. Dairy Sci. 102:8221-8233. https://doi.org/10.3168/jds.2019-16625.

Wilmink, J. B. M. 1987. Comparison of different methods of predicting 305-day milk yield using means calculated from within-herd lactation curves. Livest. Prod. Sci. 17:1-17. https://doi.org/10.1016/ 0301-6226(87)90049-2.

\section{ORCIDS}

K. B. Wethal ๑ https://orcid.org/0000-0002-1268-0854 M. Svendsen () https://orcid.org/0000-0002-2589-0017

B. Heringstad $\odot$ https://orcid.org/0000-0001-7388-3893 